Primljen / Received: 24.10.2012. Ispravljen / Corrected: 25.1.2013.

Prihvaćen / Accepted: 30.1.2013.

Dostupno online / Available online: 15.2.2013.

\section{Risk register developement and implementation for construction projects}

Authors:

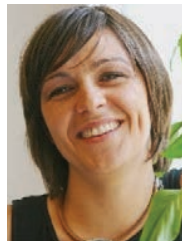

Ivana Burcar Dunović, Ph.D. CE

University of Zagreb

Faculty of Civil Engineering

iburcar@grad.hr

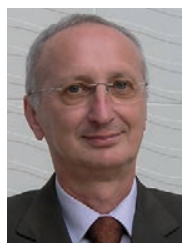

Prof. Mladen Radujković, Ph.D. CE

University of Zagreb

Faculty of Civil Engineering

mladenr@grad.hr

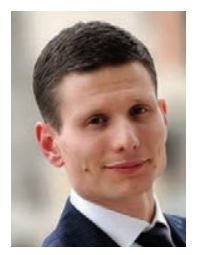

Asst. Prof. Mladen Vukomanović, Ph.D. CE

University of Zagreb

Faculty of Civil Engineering

mvukman@grad.hr

\section{Ivana Burcar Dunović, Mladen Radujković, Mladen Vukomanović}

Preliminary note

\section{Risk register developement and implementation for construction projects}

An original methodology for development of the risk register system for construction projects in Croatia, with its integration into the risk management process, is presented in the paper. The application of the methodology enables development of the risk register that assumes the central role in the risk management process. In this form, the risk register becomes an active link between the risk and knowledge management on construction projects, through which the project management is raised to a higher level, and hence the overall success of project management activities is also increased.

\section{Key words:}

risk register, construction projects, risk management, risk components and characteristics

Prethodno priopćenje

\section{Ivana Burcar Dunović, Mladen Radujković, Mladen Vukomanović}

\section{Razvoj i implementacija registra rizika kod gradevinskih projekata}

U radu se prikazuje originalna metodologija razvoja sustava registra rizika za gradevinske projekte u Hrvatskoj kao i njegova integracija u proces upravljanja rizicima. Primjena metodologije omogućuje kreiranje registra rizika koji ispunjava očekivanu ulogu središnjeg alata za proces upravljanja rizicima. U tom obliku registar rizika postaje aktivna poveznica između upravljanja rizicima i upravljanja znanjem u građevinskim projektima čime se upravljanje projektima podiže na višu razinu, a time i uspjeh upravljanja projektom.

Ključne riječi:

registar rizika, građevinski projekti, upravljanje rizicima, komponente i karakteristike rizika

Vorherige Mitteilung

\section{Ivana Burcar Dunović, Mladen Radujković, Mladen Vukomanović}

\section{Entwicklung und Implementierung eines Risikoregisters für Bauvorhaben}

Die vorliegende Arbeit stellt eine originale Methodologie für die Entwicklung eines Risikoregisters für Bauvorhaben in Kroatien dar, sowie für die entsprechende Integration in den Prozess des Risikomanagements. Die Anwendung des Verfahrens erlaubt die Erstellung eines Risikoregisters, das die erwartete Rolle eines wesentlichen Hilfsmittels im Prozess des Risikomanagements erfüllt. In der gegebenen Form wird das Risikoregister zu einem aktiven Bindeglied zwischen Risiko- und Wissensmanagement in Bauprojekten, und hebt somit das Projektmanagement und den dazugehörige Erfolg auf ein höheres Niveau an. 


\section{Role of risk register in risk management}

Risk management is a "formally structured process for systemic risk identification, analysis and response throughout the life span of the project in order to achieve an optimum level of risk elimination or control' [1]. Unlike corporate risk management, one of determinants of the project risk management is the focus on the project itself, which means that it deals with risk events that can impact project objectives, most often the scope, quality, time and costs. Risk management is currently considered as an mandatory part of project management, and also as an integral part of successful project management. The process is iterative and continuous, and is composed of a series of cycles through which the level of understanding risks is increased. In addition, it is applied throughout the whole life cycle of the project.

In the scope of various research approaches, numerous attempts have been made to propose the best way for identifying and preparing input data on project risks and, at that, a highly significant role of risk registers has been noted. In this paper, the authors describe characteristics and possibilities that a risk register should have to meet the needs of construction projects, as well as the way in which such register should be integrated into the risk management process. Various authors have interpreted risk registers in many ways, and their approaches can broadly be classified into three categories [2]:

1. risk register is a byproduct - a document that contains information about risks;

2. risk register is a useful tool for risk management; and

3. risk register is the central part of the risk management process.

Initial studies on risk management [3] define risk register as "... repository of knowledge corpus..." and as "...starting point for analyses and plans..." and hence interpret it as the main tool for an integrated analysis of risks relating to time, costs and technical issues. The perception of risk register is developing toward considering it as an comprehensive tool for the risk assessment system, which is used as a formal method for risk identification and categorization, and as a tool for developing a cost effective method for risk control [4].

Risk register is an unavoidable part of the current risk management methodologies [6-10]. Each one of these methodologies proposes what information should be contained in this register. Nevertheless, only two methodologies have placed the register in the central part of the process. The first one is the CIRIA methodology that consists of ten steps [10]. Here the register is considered as an outcome of risk assessment, and as a tool for storage and control of risk management processes. The ATOM methodology [7] also integrates the risk register into the risk management process, using it not only for storing data but also for monitoring processes through regular inspections, and for the final inspection of projects.

However, not many studies have been made on risk registers, their structure, and possible development trends. Foreign companies wishing to gain a competitive edge on the market use risk management tools in their work, and so risks are stored in some form of register in 67 percent of cases, in either paper or electronic format, while $78 \%$ of such companies have developed their own IT systems [5]. The methodology of developing risk registers for construction projects is presented in the next section.

\section{Risk register development methodology}

The first step in the risk register development methodology is to define expectations and current practice relating to the use of risk registers, and analyse perceptions about possible characteristics and capabilities of a risk register. In that respect, a pilot study in form of survey, targeted on high ranking officials in ten greatest construction companies, was conducted in the scope of the research project No. 082208 "Management of risks and resources in construction projects" financed by the Ministry of Science and Technology (1996$2000,2003-2006)[2,11]$. The results have revealed that companies in which risk management procedures are operated in some form or other actually store risk data, either periodically or regularly, but without a formal procedure that would regulate implementation of such procedures. The structure for systemic storage of risk data does not exist and so the procedure is conducted in form of unstructured written reports. This is due to the absence of a systemic risk management. Construction companies that partly manage their projects through identification and assessment mostly use the so called risk checklist. This practice has been registered in companies whose seat is in Western European countries where risk management is more commonly implemented in construction projects. All respondents agree that the role of risk register is positive in that it enables improvement of company operations, while increasing the level of risk management in construction projects. In addition, they would agree on using it but only in form adjusted to construction projects and companies [2,11]. In the scope of the mentioned survey, the respondents were asked to select three statements that best describe the term "risk register":

- the main tool for an integrated risk analysis,

- comprehensive risk assessment system, as a formal method for the identification, quantification and categorisation of risks, and for definition of means needed to determine an efficient method for the control of such risks,

- tool for storing and documenting data generated through risk management that enables conscious evaluation and management of risks in the scope of the decision-making process.

When asked to define the most important capabilities of risk registers, they selected the following options:

- storing details of all risks identified in the beginning and during the life span of the project,

- determining risk priorities in terms of probability of occurrence and possible effects on the project,

- documentation on the source of risks, response to risks, and classification of risks,

- systematic data storage aimed at forming a "knowledge base" to be used on future projects. 
During the work on pilot projects, it has become clear that the basic prerequisite for risk management is to learn to think about risks, which requires a good definition and understanding of their components and characteristics. That is why the analysis of components in concepts available in literature was conducted in the second step [2]. During the literature research, it was observed that different concepts and approaches to risk result in different approaches to components and hence also in different terminology, definitions and explanations. The analysis has shown that in literature the source and cause, and the consequence and impact, are explained with synonyms. When we are discussing risks on construction projects, the source and cause can be considered as synonymous and so, according to this model, the cause is left out of the concept, unlike consequence and impact that have different meanings and functions - a consequence is a component, and the impact is its characteristic. The driver, which is encountered in literature also as driver, also has different meanings: from the event that will start the risk management process, via indicator that will lead us to believe that the risk event will actually occur, to the event that will be started by the risk event itself. The systematisation and synthesis of risk data has resulted in development of the risk model (Figure 4) that enables us to gain more knowledge about the project [12]. This model also enables systematisation of all data related to risks in the project, which is the basis for developing the structure of risk register data.

The third step in the development of risk register is the classification of risks that are needed for systematic risk management, primarily for risk identification, which lowers the possibility of their prediction, and is widely used to define responsibility. A whole array of classification systems has been developed, depending on the type of industry, profession, field of action, or type of project. A great significance of structuring and hierarchy in the project can be seen in the most widely spread tool for project management, which is the Work Breakdown Structure (WBS) whose purpose is to present work on the project through hierarchically structured, defined packages that can be managed as a foundation for planning, communication, reporting and allocating responsibilities on the project. If the entire hierarchical WBS approach is applied on risks, by structuring risk management problems to the level that is necessary to understand risk exposure to enable efficient management, the risk structure called Risk Breakdown Structure (RBS) is created [21]. Although the possibility of selecting an another risk structure according to available data is not excluded, the RBS is used for risk register in this paper because its structure is the result of research conducted in the scope of previous research projects 082005 and 082208 "Management of risks and resources in construction projects" financed by the Ministry of Science and Technology (1996-2000, 2003-2006) [21-23], with modification of source as related to technical documentation (Figure 1) [2]. The technical documentation was moved from the second level to the third level, within a new element in the second level - Technical sources together with technology.

The implementation framework enabling the risk register to take its proper role was defined in the fourth step. As risk management is closely related to the decision making process, the application of phases in the decision making process (problem definition, evaluation of possible solutions, selection and application of an optimum solution, decision implementation monitoring) has lead to forming project risk management phases that most often include identification, analysis of impact and evaluation of risk, response or interpretation of risk, and implementation of plan and risk control. There are many methodologies that allocate risk management processes in different ways, which is dependent on their approach to risk management $[8,10,13-20]$. Standard tools for risk management are risk identification checklists or risk logs that are used for risk monitoring. However, only a few of these

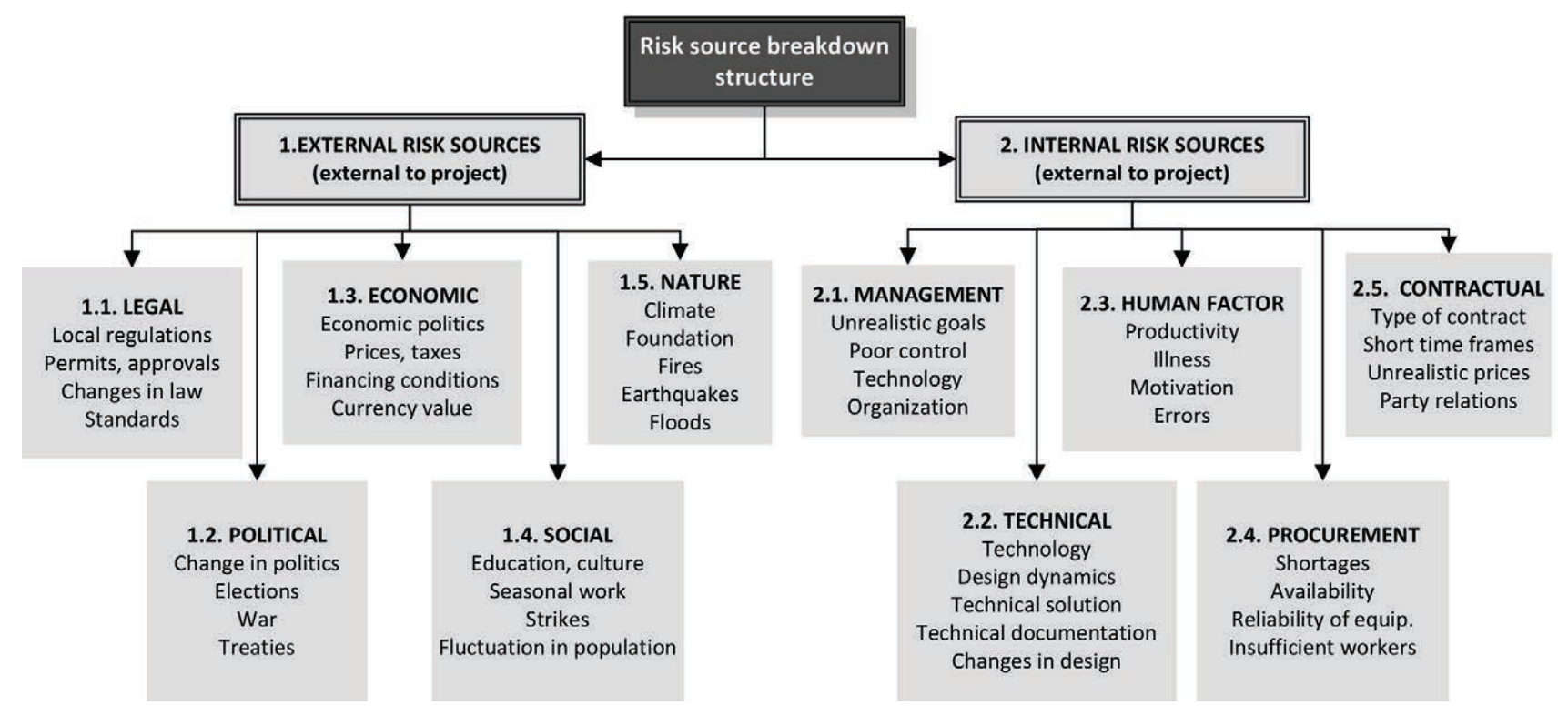

Figure 1. Risk source structure for risk register on construction projects 
methodologies have gathered together these tools in risk register. One of first methodologies that mentions risk register in which data are stored throughout the risk management process is the risk control methodology known as CIRIA [10]. But it involves only one risk register level - the project level. Recent research on risk registers [7] has enabled development of the system called the Risk Register Database System, which comprises the risk register and tools in risk assessment in the automobile industry. In order to meet risk register expectations and perceptions [11], the risk register system with two register levels (Figure 1) has been developed in this study, and will be presented in the following section.

\section{Structure and content of risk register for construction projects}

Viewed from the aspect of one participant (which is most often the contractor), the model of the risk register system contains two register levels (Figure 2). The Project risk register enables us to record risk data in all phases of the risk management process in order to gather data for each construction project. In addition to data recording, this part of the register also has the role of the platform and tool for risk management and communication in the project. By enabling continuous risk monitoring, the risk register becomes the medium for communication between key participants in the project. The second level of the model is the Central risk register in which data are stored about risks originating from risk register of all projects undertaken by the company. This part of the system has the role of the "knowledge base" and the tool for identifying risks in projects and, after a longer use, it also becomes the source of qualitative and quantitative risk-related information. In addition, being the source of data on responses to risks, and on monitoring and control of risks, it enables one to evaluate efficiency of individual responses and actions with regard to risk consequences. Planned and real data are needed for proper

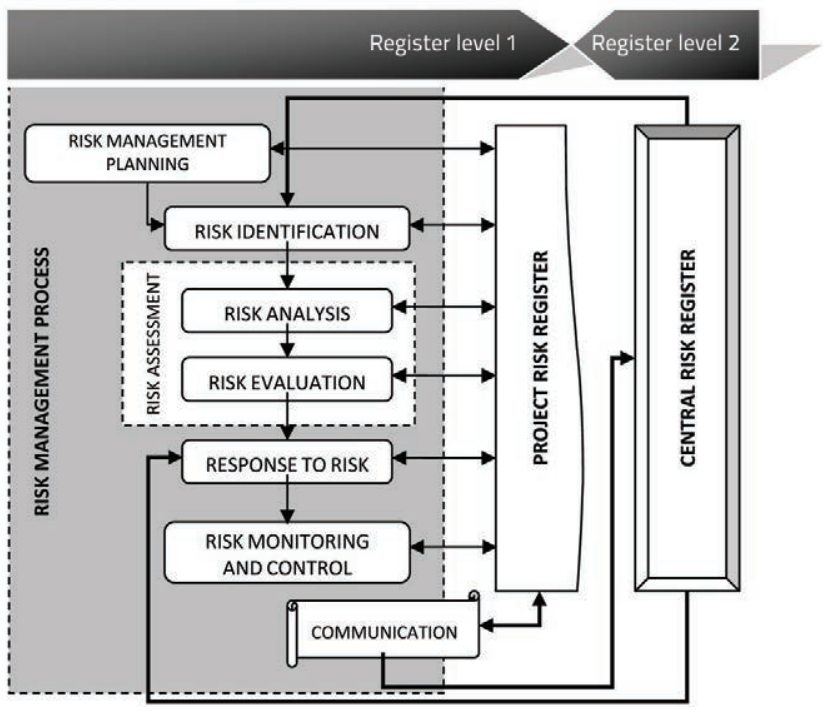

Figure 2. Model of a risk management system fulfilment of the main function of the central risk register, as it is on the basis of comparison of these data adequate conclusions can be made on the "behaviour" and "reactions" of risks. If data are available about changes that have caused modification of some components or characteristics of risks, then more reliable data and knowledge on the sources and drivers of risks will be obtained, while by comparing initial response plans with real-life actions and consequences, we are able to measure quality of risk management in a construction company. Creation of data base containing data about good and bad actions will undoubtedly spur development in terms of improving current practices in the management of construction projects.

One of primary requirements relating to the project risk register is the quality of input data. That is why the risk register must be adjusted to the risk management level applied in construction companies. In addition to careful selection of the data and structure so as not to burden the process will superfluous data, the risk register structure must be prepared for both the basic and advanced use. The structure, content and functionality of risk register must correspond to the expected level of use, but they also must enable advanced use, not only for the sake of users familiar with advanced risk management practices, but also to enable such users to monitor and even encourage development or the risk register.

The data and structure of risk register for construction projects originate from the risk model and risk management processes, which means that they must encompass all risk components and characteristics in all phases of the risk management process [24].

Based on storage capabilities and structure, two basic groups of data can be differentiated:

- project-level data describing those characteristics of the project that are directly or indirectly related to risks, and

- risk data that describe risk components and characteristics that are needed in order to generate information for the risk management process (Figure 3).

From the aspect of phase in which they were generated, the data are generally grouped into three categories:

- planned data,

- monitoring data, and

- final (real) data.

During risk management, the planned data are the result of initial identification, evaluation and response to risk, while for the project, planned data are related to completion time and costs. In both cases, monitoring data are records on planned data during the monitoring phase, while final (real) data are records on real results at the end of the project, which includes risk closing data. Risk data are based on the risk model for construction projects that has been developed during analysis of risk data from literature, and based on the study of existing risk mechanisms and models [12] (Figure 4).

Basic components by which the risk mechanism is presented are the event/risk, source, driver, consequence, and impact. 


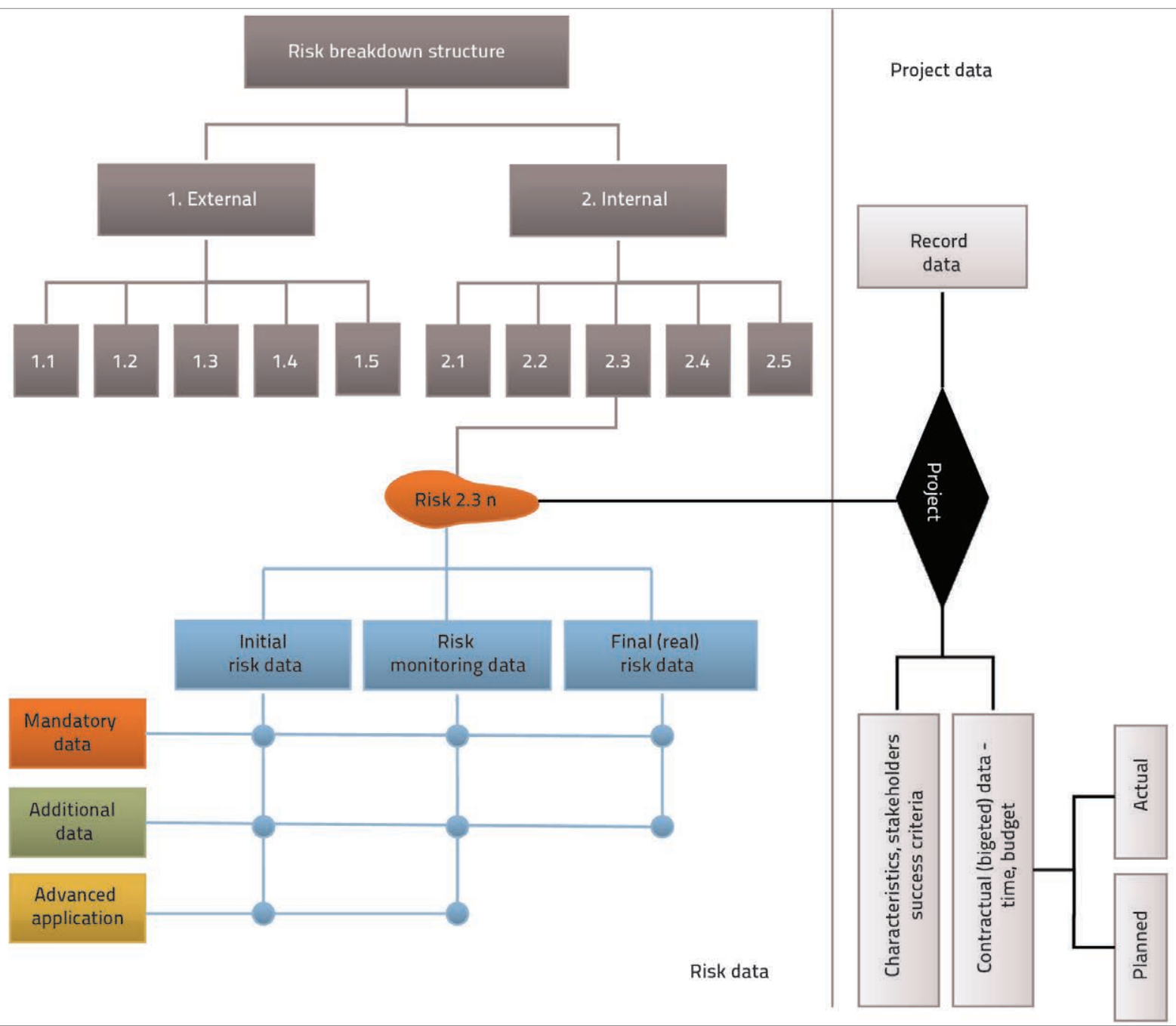

Figure 3. Risk register data structure

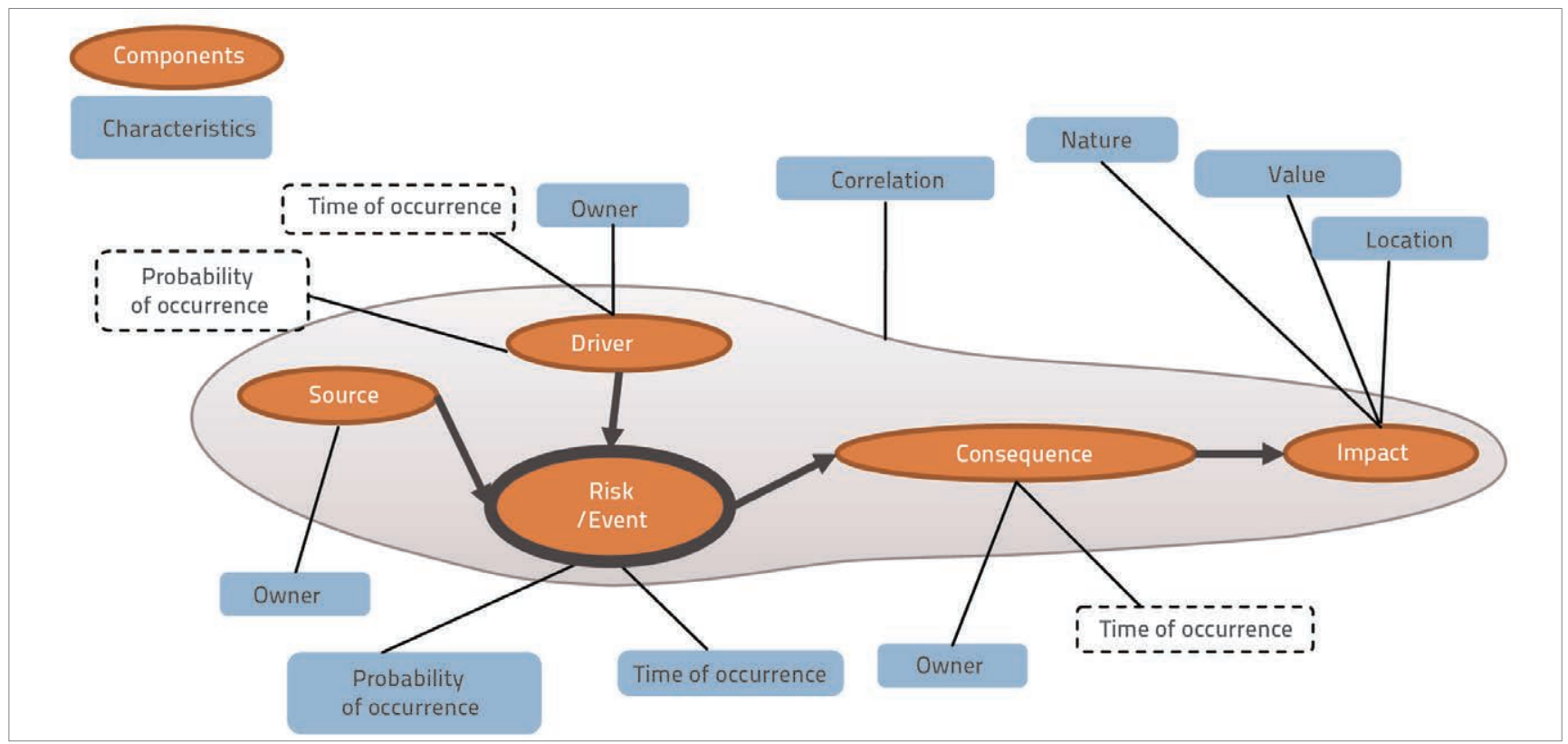

Figure 4. Risk components and characteristics 
Each of these components has some characteristics by which it is described. Therefore, the risk is fully described through components and their characteristics.

The event/risk is the main part of the model. It represents an uncertain occurrence, action or event the occurrence of which causes a consequence.

The source of risk is defined as an area of human activity or a natural phenomenon from which the risk is generated, or from which the possibility that the risk might occur is generated. It exists either in the project or outside of the project, and does not have a variable characteristic. Its important characteristic is the owner i.e. the participant because of which a source has come to exist.

The consequence is the condition, occurrence or event that has occurred precisely because of the occurrence of an event/risk, and which affects the success of the project, i.e. the project objectives, through the risk impact. Significant characteristics of the impact are the nature, size and place that define in which way the risk will impact the project and its objectives, i.e. to what extent and on what part of the project, WBS or activity.

The next component is the driver that can be either an event or a change of condition, which leads to activation of the risk mechanism, i.e. which initiates transformation of risk into actual event. Through its actual occurrence, the risk stops being a risk and becomes a real-life event or problem to be dealt with. The risk can be described as a mechanism in a latent state that needs driver to be activated.

In addition to the source, the driver and the consequence must also have the owner i.e. the stakeholder to which the two events or occurrences are related. The time and probability of occurrence are the characteristics that are most often related to risk in general, but are related in this model to the event, which is regarded as the central component of risk. Both components could also be related to the occurrence of the driver being an event that activates the risk mechanism, while the time of occurrence could also be related to the consequence. Nevertheless, these three components occur in relatively short time intervals, and their order of precedence is known (driver-event-consequence), and so the model does not need to be burdened by the definition of time for all three components. It would be even better to present this time sequence through the occurrence of the first component, i.e. the driver, which initiates the whole mechanism but, due to insufficient understanding and practical use of driver in risk mechanism, this data will be linked to the event/risk for the purposes of this paper. The same approach is used for the probability of occurrence. The only difference is that the probability of occurrence of the drivers or consequences can here be considered in case of occurrence of alternative drivers or consequences, but this approach is used in detailed analysis of risk when the decision tree is most often used. The probability of occurrence of an event/risk, and the extent of impact, together give the risk severity which is the measure for ranking individual risks on the project.

\section{Integration of the risk register system into a business system}

\subsection{Risk register in a business system}

In order to create a central risk register for a construction company, a good-quality risk register must be prepared for each project. This can only be achieved through systematic risk management, for which an additional effort must be invested by the project manager and the company management team.

That is why this activity must be supported by an appropriate decision at the company level and by proper organisational measures aimed at ensuring its implementation. The starting idea is that no additional resources should be engaged for implementation of the central risk register. In fact, each project manager should be responsible for the risk register related to his project, while the task of storing data into the central risk register should be a regular responsibility of the project manager and should be carried out after each phase of project management. To make this feasible, the use of risk register on the project, and the process of storing data into the central risk register, should not be complicated and should not require much additional effort in the project closing phase. On the other hand, it should not be

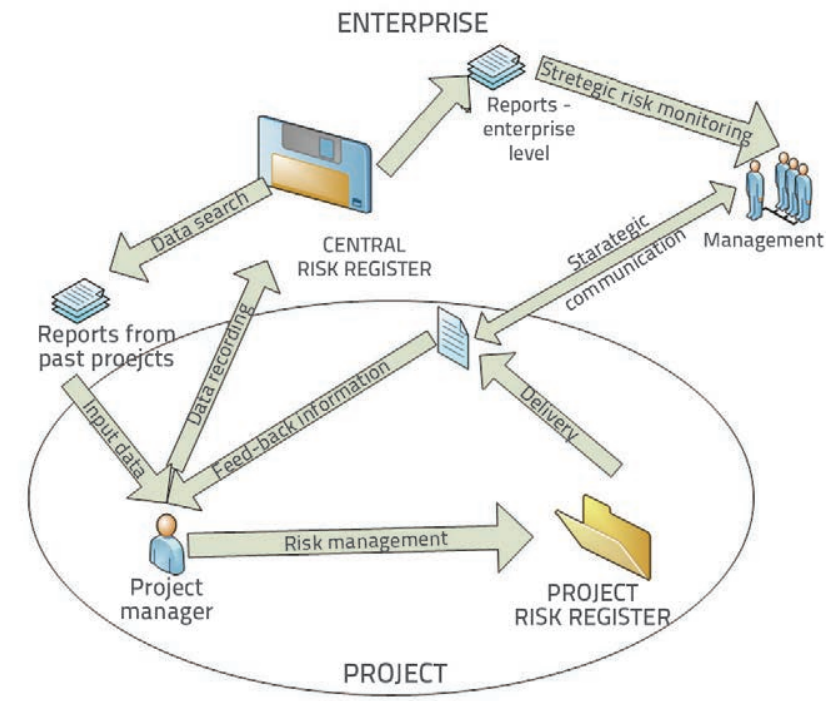

Figure 5. Risk register in a business system

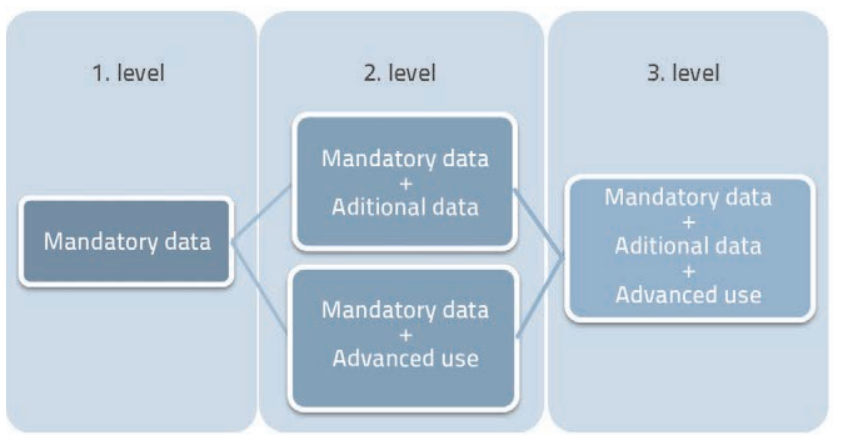

Figure 6. Risk register levels 
a completely automatized task but rather a conscious activity aimed at providing good-quality data to the central risk register. Once the data are approved by the company management and stored into the central register, the change is possible only by means of a special procedure, with proper justification, and subject to approval by the company management, Figure 5.

The use of this risk register can be realized through three levels that differ from each other by the level of detail of the information about risks and the project, and by the use of analysis during risk management. Starting from mandatory data, and including additional data and advanced use, the level of use will grow either through insertion of additional data or through advanced use, until the highest level that includes all three data levels (Figure 6).

\subsection{Risk management procedures using Risk register system}

The actual generation of data in risk register is based on the logical sequence of risk analyses conducted at individual phases of risk management, and is certainly dependent of the level of use of the risk register. Procedures that need to be introduced into the business system in order to integrate the risk register system into the project management, and hence into the various project management processes, are presented in the diagram (Appendix 1). The procedures should follow the following activities:

1. Project planning in risk register

a. Project opening - entering data at the project level

b. Entering new risks in the Project Risk Register

c. Storing data into the Central Risk Register

2. Project monitoring in risk register

a. Project data monitoring

b. Monitoring existing risks in the Project Risk Register

c. Entering new risks into the Project Risk Register

d. Closing risks in the risk register

e. Storing data into the Central Risk Register

3. Closing project in risk register

a. Storing data into the Central Risk Register

The project opening in risk register occurs at the moment when the project starts in the scope of a business system. The process starts by entering, at the project level, the data that are needed for connecting risk data with requirements, limitations, characteristics and circumstances related to the project, and for integrating the project management and risk management. The project level data structure is formed of five groups (Table 1), while the risk level data structure is given in Table 2 .

The "life" of a risk in the project risk register begins by opening the risk, i.e. by entering the identification data, which initiates the data entering process at the risk level. The identification phase comprises identification of risk components and their qualitative characteristics and, at that, mandatory and additional data are differentiated. The Central Risk Register is consulted in order to find risk lists for selected criteria from past projects.
Table 1. Data structure at the project level

\begin{tabular}{|c|c|}
\hline Basic (registration) data & $\begin{array}{l}\text { Project code } \\
\text { Project name } \\
\text { Name of project manager }\end{array}$ \\
\hline Stakeholders in the project & $\begin{array}{l}\text { Name of stakeholder } \\
\text { Role on the project }\end{array}$ \\
\hline Key criteria for project success & $\begin{array}{l}\text { Success criteria } \\
\text { Priority }\end{array}$ \\
\hline Project characteristics & $\begin{array}{l}\text { Type of project } \\
\text { Size of project } \\
\text { Type of project } \\
\text { Technology } \\
\text { Location } \\
\text { Population density at location } \\
\text { Topography of location } \\
\text { Type of contract } \\
\text { Type of investment } \\
\text { etc. }\end{array}$ \\
\hline Contract data & $\begin{array}{l}\text { Planned cost } \\
\text { Planned date of start } \\
\text { Planned duration } \\
\text { Actual cost } \\
\text { Actual date of start } \\
\text { Actual duration } \\
\text { etc. }\end{array}$ \\
\hline
\end{tabular}

The information obtained serves as the basic tool for risk identification on the project. This is followed by the risk evaluation phase which starts by searching through data contained in the Central Risk Register in order to gain actual risk data based on criteria selected to this effect. Just like in the identification phase, these data will be used as the starting tool for the project risk analysis. This will be followed by quantitative determination or risk impacts.

The risk analysis phase ends by risk evaluation according to the severity of risk impact. This is followed by establishment of a ranking list to be used in the response phase, and the risk acceptability information is calculated in order to instruct the user about the way in which he should deal with a particular risk. Although the ranking can be made regardless of the priority of the success criterion in question, this risk register structure also enable the use of multicriteria methods that take into account significance of individual criteria affected by a particular risk. Just like in two preceding phases, the risk response phase starts by searching through the Project Risk Register in order to find actual risk response data from previous projects, and the information found is used to form the response strategy. The mandatory data on risk response, and mandatory data on risk characteristics from the identification phase, constitute the first level of use of the Risk Register System, where the response phase follows after identification. In the second or third level of use the risk evaluation phase follows after risk evaluation and ranking. When defining the type of response, five risk response options can be selected: acceptance (absorption), reduction, transfer, avoidance of risk and risk elimination [10]. Each type of answer can be implemented in different ways, as described by the data description of response, i.e. the method can be 
Table 2. Structure of risk register data at the risk level

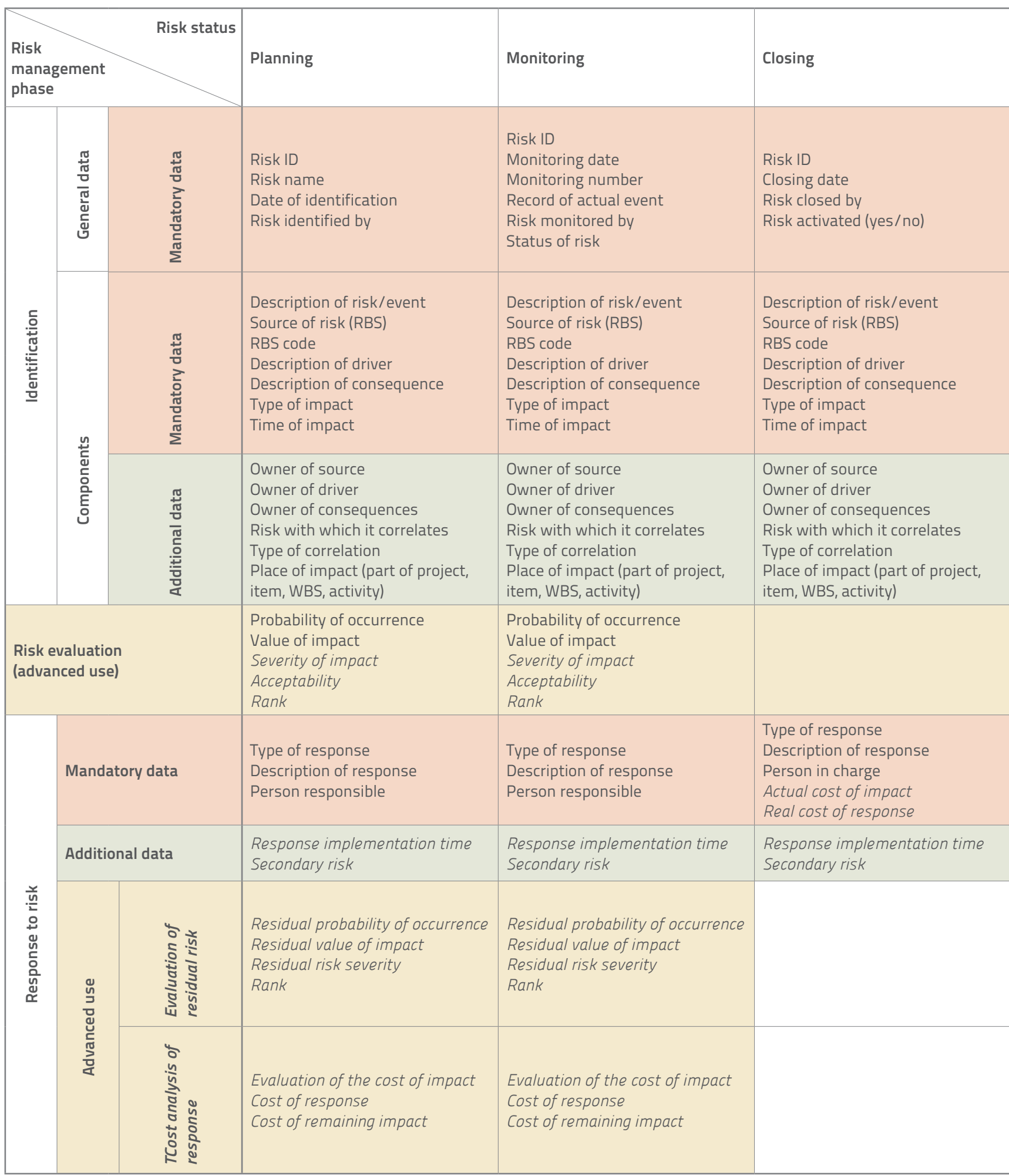

defined more closely by specifying data about measures taken or measures to be taken to implement the response that has been selected, while the person in charge is responsible for response definition and implementation. Additional risk response data include planned response implementation time which enables us to monitor response over time, but can also serve as indication about whether the response is related to the source and driver or to the consequence and impact, i.e. fire fighting. One of possible consequences of the response to risk is the secondary risk which will be entered by name and/or number under which it has 
been or will be registered. The next group of data is related to the advanced use of the project risk register, and it comprises risk evaluation prior to and after the response (residual risk), and the response efficiency analysis, i.e. determination and use of quantitative data about the risk. Residual severity of the selected response can also be defined based on the evaluation of the residual probability of occurrence and residual impact. The data on residual cost and cost of response are highly significant for selecting the type of response. Their sum is compared to the initial total cost of risk in the scope of the response efficiency evaluation.

The project monitoring in the Risk Register System follows after adoption of the Risk Management Plan which is approved at the business system level, while data generated in the risk planning processes are stored in the Central Risk Register. Before the risk can be monitored in the project risk register, it is necessary to enter the actual start of the project, and project management changes according to criteria relating to project success and project participants. This is followed by revision of the project management plan which is prepared at the start of each project management phase, or after significant changes to the project. If this period is longer, then it is advisable to revise the risk management plan every two months.

The monitoring number and monitoring date, and also the name of person who enters the monitoring data, has to be entered for each risk. At this point, the project manager is required to make record about the event in an unrestricted form. This information explains more closely the change that has occurred on the project and is significant for the risk, i.e. for its modification. The risk status is used to rapidly indicate the change in risk status. It should be noted that the risk status is marked inactive prior to occurrence of the driver and, after occurrence of the driver, the status is marked as active and finally as closed.

The risk monitoring procedure includes monitoring of all risks in the register, and introduction of new risks into the register. In case of risks already in register, the checking is made to determine whether a change has occurred during implementation of the risk management process in the register of risks explained for the planning phase (identification, evaluation, response), and procedures for the planning phase are implemented to check whether new risks have occurred. Changes are noted in the Project Risk Register, in the group containing the risk monitoring data. Therefore, in the monitoring phase, the project risk register will have the same content and structure, except for general data where the number and name of risk are kept, while the data needed for monitoring are added. The risk monitoring phase results in the Revised Risk Management Plan which is approved at the business system level, while the data generated during the risk monitoring processes are stored in the Central Risk Register. The data generated at the time of risk closing are particularly significant for adding and updating data in the Central Risk Register, as these are actual data about the risks. It is precisely these data that will be searched when information about experience from previous projects is needed. Compared to initial data and monitoring data, some data have been left out because of their nature due to which they can not assume a real form (e.g. probability of occurrence), while other have been left out due to loss of function in the closed condition (e.g. strength).

The most interesting data for storing in the Central Risk Register are the real data about components, but also the real data about the response, its effect (i.e. about the remaining risk) and correlation with other risks. To enable statistical treatment of risk occurrence in the Central Risk Register, it is also necessary to indicate whether the risk has been activated or not. It is on this basis that the frequency of occurrence of a particular risk can be determined. Here also the data are divided with regard to the level of use, and so all retained data will belong to the same level, except for the fact that the real cost of impact, and the real cost of response, will become mandatory data as they have to be registered for use on future projects.

The risk closing will occur in two cases: if the risk is activated during realization of the project, or if the project is completed. The risk closing is an important aspect of project closing as it is precisely through this part of risk management that lessons learned can be analyzed and stored. This is why the lessons learned have to be analyzed after the closing of all risks and after data have been stored in the Central Register. This activity is followed by project closing in the Risk Register.

\section{Conclusion}

This paper presents an original risk-register development methodology, and the implementation of this methodology in the management of risks in construction projects. The basic purpose of the risk register for management of construction projects is to permanently store data on the risks experienced on previous construction projects, and thus to create a source of data for managing risk on construction projects. However, the proposed Risk Register System is not only a document containing project risk data, but also a central tool and platform for the risk management process, and a source of information needed to identify risks and responses to risks, as well as for communication on the project.

The risk register system contains two levels of registers: project level and central level. The Central Risk Register is created by storing data from the Project Risk Register through the risk management process and this during the entire life of the project. Thus the project manager is given an important role in the creation and maintenance of the Risk Register System.

The input and structure of data follow the risk management process, and in this way they fulfil the role of storing and documenting the risk data generated through the risk management process. This in other words means that the input and output data needed for each phase can be stored and documented. The study has confirmed that the structure selected is favourable for development of an appropriate software support through relational databases. Thus it is possible to form adaptable reports that are needed for including the Risk Register System in the communication on the project. 
The contribution of the Risk Register System's implementation into the civil engineering practice will be manifested in several areas. The use of risk register will improve understanding of risks, and will advance risk management practices on construction projects, which will in turn contribute to the success of such projects. In most cases, current risk management tools do not comprise the entire process, but are limited to risk identification and evaluation only. The risk register system has been created for systematic data storage and for supplying the decision making data throughout the life of the project. It enables continuous monitoring of risks and hence it has become a means of communication among participants in the project, as well as an efficient risk monitoring and control tool.

Learning based on past experience, and collection of best practice resources, is of crucial significance for project management, not only on the level of individual projects, but also on the company level. Due to the fact that it enables systematization of data about components and characteristics of risks, as well as planning of management steps, actions and consequences, the Central Risk Register is an integrated risk-based knowledge management tool which gathers together organisational, procedural and technical knowledge. The risk register system is creating foundations for development of an expert system that would serve as "knowledge base" for the Central Risk Register, and would assume an advisory role in the phase of identification and selection of an appropriate risk response.

Project management without an efficient and integrated risk management throughout the whole project life cycle is a very hard and inefficient job for project managers, and such projects are often doomed to failure. Project management founded on an integrated risk management process, and on knowledge based on risks from pas projects, enables a safer orientation of project toward its goals and, at that, the risk register plays a central role by ensuring integration of such goals.

\section{REFERENCES}

[1] Al-Bahar, J.F., Crandall, K.C.: Risk Management in Construction Projects: A Systematic Approach for Contractors, presented at the CIB 90 Conference, Sidney, 1990.

[2] Burcar, I.: Struktura registra rizika za građevinske projekte, Magistarski rad, Zavod za organizaciju i ekonomiku građenja, Građevinski fakultet Sveučilišta u Zagrebu, Zagreb, 2005.

[3] Williams, T.M.: Using a risk register to integrate risk management in project definition, International Journal of Project Management, vol. 12, pp. 17-22, 1994.

[4] Barry, L.J.: Assessing risk systematically, Risk Management, vol. 42, pp. 12-17, 1995.

[5] Patterson, F.D., Neailey, K.: A Risk Register Database System to aid the management of project risk, International Journal of Project Management, vol. 20, pp. 365-374, 2002.

[6] Murray-Webster, R. \& OGC - Office of Government Commerce: Management of Risk: Guidance for Practitioners: Stationery Office, 2010.

[7] Hillson, D., Simon, P.: Practical Project Risk Management: The Atom Methodology: Management Concepts, Incorporated, 2007.

[8] Actuarial Profession i Institution of Civil Engineers, RAMP - Risk Analysis and Management for Projects: A Strategic Framework for Managing Project Risk and Its Financial Implications: Thomas Telford, 2005.

[9] Simon, P., Hillson, D., Newland, K.: Project Risk Analysis and Management (PRAM) Guide: APM Group Limited, 1997.

[10] Godfrey, P.S.: Control of risk a guide to the systematic management of risk from construction. London: CIRIA, 1996.

[11] I. Burcar and M. Radujković, Risk Registers in Construction in Croatia, in Proceedings of the Twenty First Anual Conference ARCOM 2005, London, 2005, pp. 171-178.

[12] Burcar, l., Radujković, M.: Risk model for construction projects risk register system, in Construction facing worldwide chalenges - Joint 2008 CIB W065/W055 Commissions Symposium Proceedings, Dubrovnik, 2009, pp. 1050-1059.

[13] Risk Management, AS/NZS 4360:1999, ed: Homebush, NSW, Standards Australia, 1999.
[14] Chapman, C. B., Ward, S., Ward, S.C.: Project Risk Management: Processes, Techniques and Insights: Wiley, 2003.

[15] Bartlet, J., Chapman, C., Close, P., Davey, K., Desai, P., Groom,

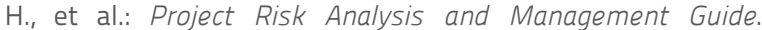
Buchinghamshire: APM Publishing Limited, 2004.

[16] Flanagan R., Norman, G.: Risk Management and Construction: Blackwell Scientific, 1993

[17] Jannadi O.A., Almishari, S.: Risk Assessment in Construction, Journal of Construction Engineering and Management, vol. 129, pp. 492-500, 2003.

[18] Wideman, R.M.: Project and Program Risk Management: A Guide to Managing Risk and Opportunities. Dexel Hill, PA: Project Management Institute (PMI), 1992.

[19] Carter, B., Hancoc, T., Morin, J.M., Robins, N.: Introducing RISKMANThe European Project Risk Management Methodology, NCC Blackwell: NCC Blackwell, 1994.

[20] Smith, P.G., Merritt, G. M.: Proactive Risk Management: Controlling Uncertainty in Product Development: Productivity Press, 2002.

[21] Radujković, M., Burcar, I.: Risk Breakdown Structure for Construction Projects, 3rd International Conference on Construction in the 21st Century, CTIC-III, Atena, Greece, 2005, pp. 164-169.

[22] Pejović, T.: Risk sources and structure in construction project planning, Master thesis, Faculty of Civil Engineering, Department for construction management and economics, University of Zagreb, Zagreb, 1997.

[23] Radujković, M.: Risk Sources and Drivers in Construction Projects, u Managing risks in projects, London, E\&FN Spon, 1997. Str. 275-283.

[24] Burcar Dunović, I., Radujković, M., Vukomanović, M.: Risk Register System for Construction Project Management, 7th annual international symposium „Economic and Management Processes in Building Industry and Investment Projects", Bratislava, 2007, pp. 26-33. 

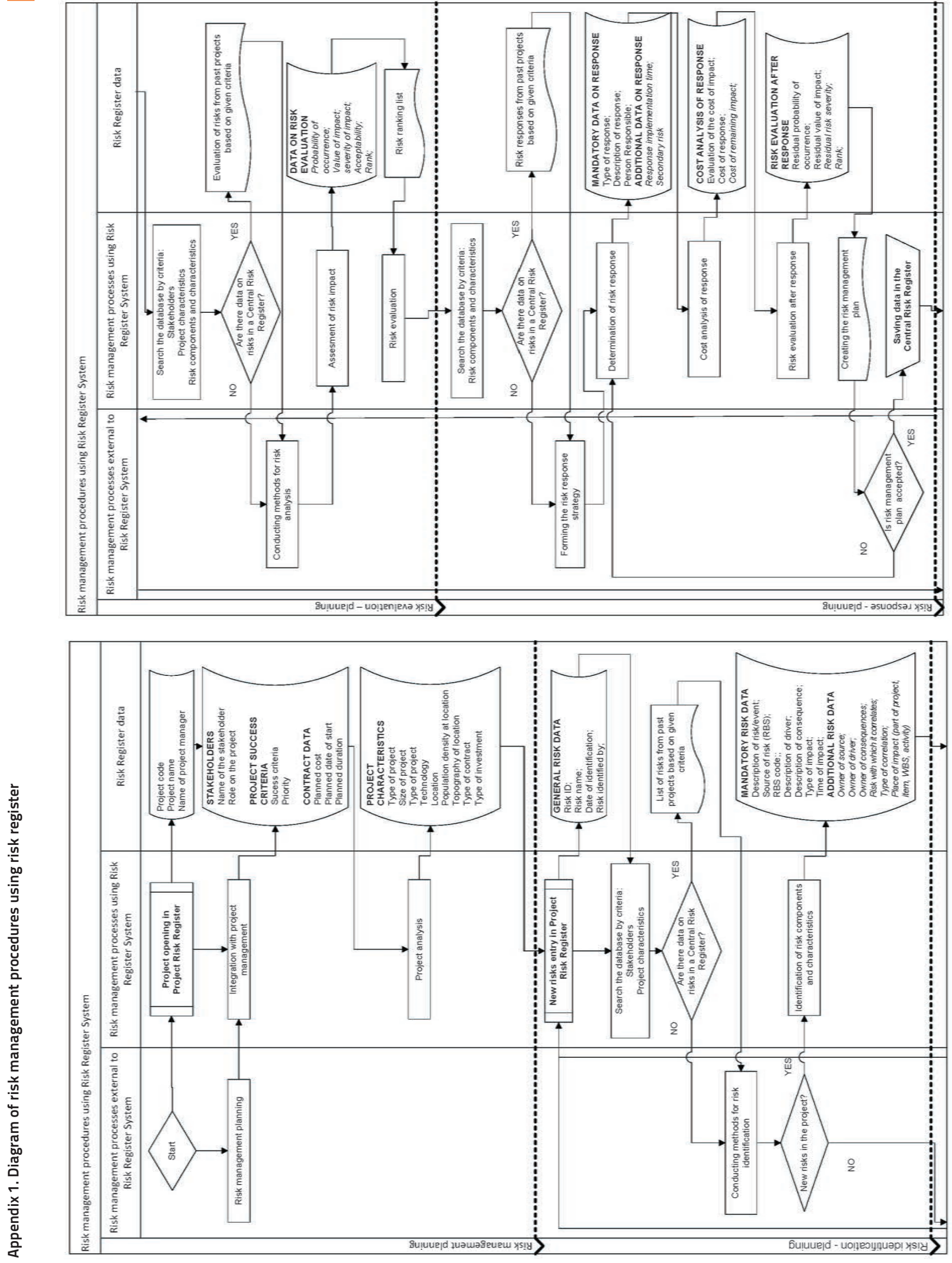

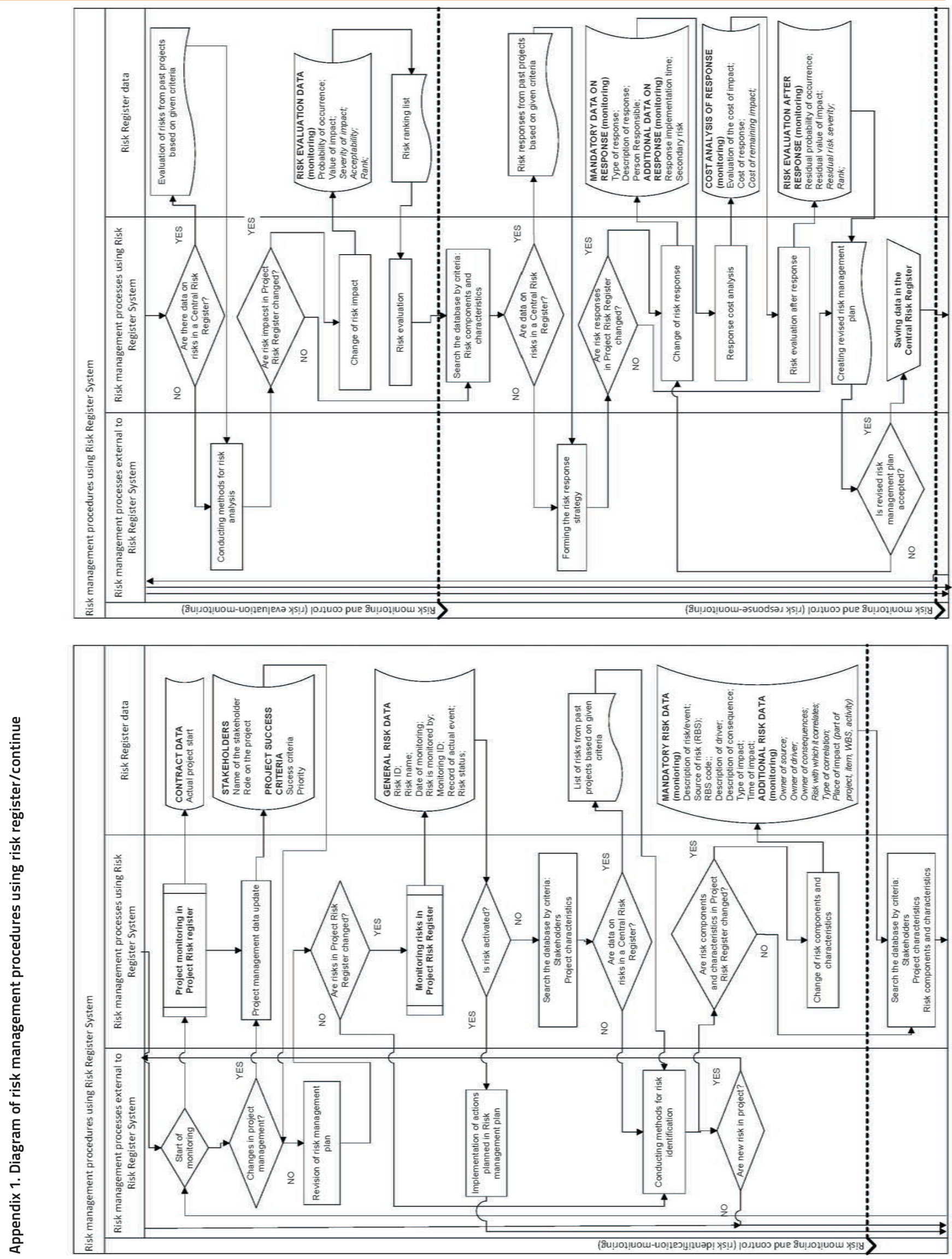


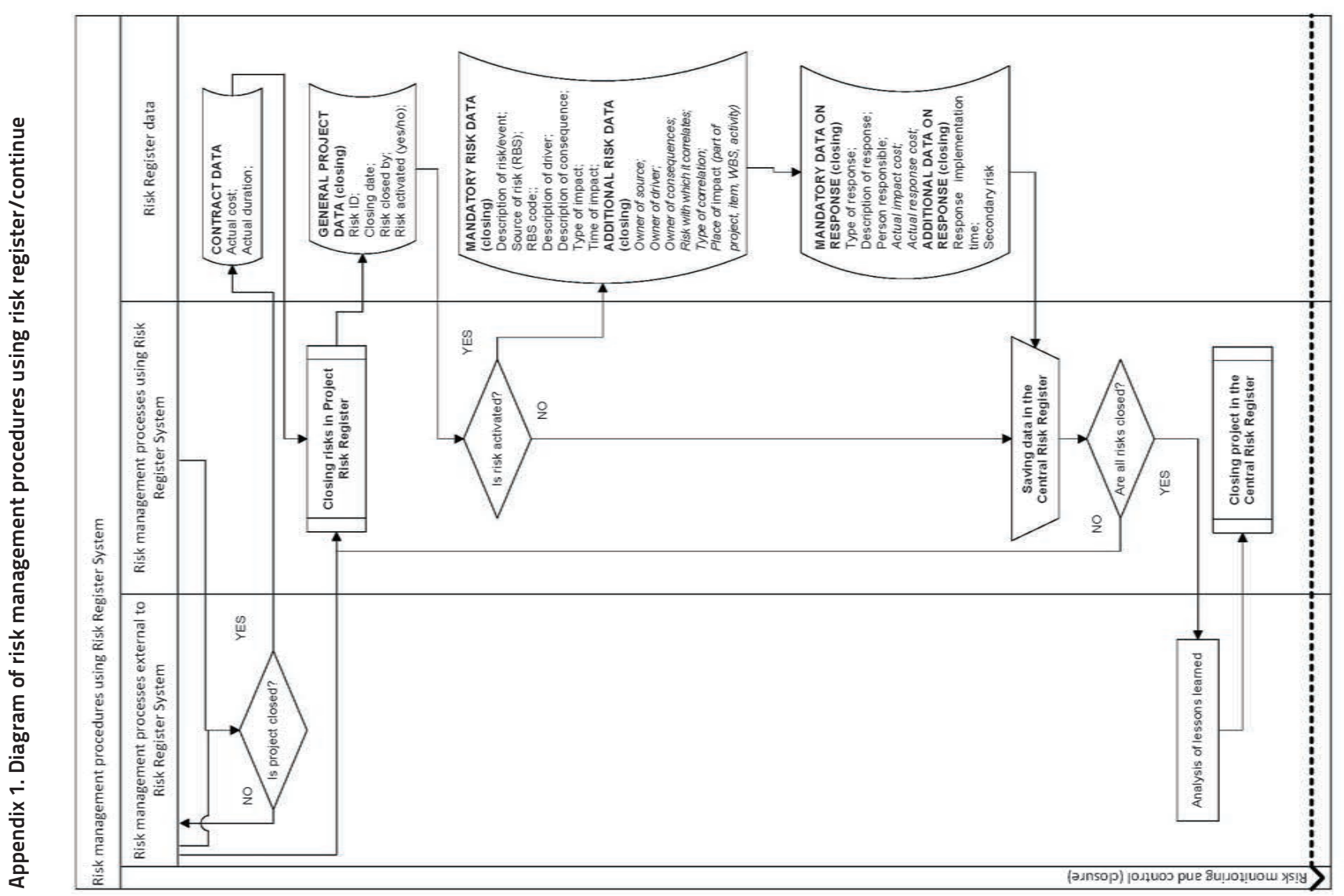

